\title{
Operational Excellence and the Implications for Health, Safety and Environmental Performance in the Oil and Gas Industry
}

\author{
Muazu Hassan Muazu ${ }^{*}$, Rosmaini Tasmin ${ }^{2}$ \\ ${ }^{1}$ Dangote Business School, Bayero University Kano \\ PMB 3011 Gwarzo Road, Kano State, NIGERIA \\ ${ }^{2}$ Faculty of Technology Management and Business, Universiti Tun Hussein Onn Malaysia, \\ 86400 Parit Raja, Batu Pahat, Johor, MALAYSIA \\ *Corresponding Author
}

DOI: https://doi.org/10.30880/jtmb.2019.06.01.003

Received 16 March 2019; Accepted 7 April 2019; Available online 15 May 2019

\begin{abstract}
The rise in the cost of production, health, safety and environmental issues are some of the daring challenges faced by the oil sector in recent time. This article is aimed at reviewing literature (reports, articles and theses) and antecedents of research in operational excellence and related field in order to understand the actual problems and their root causes. The performance of the Nigerian National Petroleum Corporation (NNPC)'s refineries, health and safety, the environment and revenue generation was also discussed. The findings indicated that although operational excellence was adopted, the health, safety and environmental (HSE) performance has been falling down, as incidents and fatalities issues are rising. Oil spillage and gas flaring are no way near stopping, outdated regulations, increasing unplanned plant shutdown, refineries performing below capacity and production deferments. The paper thus concludes that the Nigerian oil sector, particularly the NNPC should imbibe risk management culture and training, deploy dynamic technologies, employ enterprise-wide risk management strategy and upgrade the entire regulatory framework governing oil and gas activities. The paper brought out the contribution of oil to the Nigeria's economy, causes of the HSE problem and revenues issues show how it could be reduced by adopting and implementing operational excellence.
\end{abstract}

Keywords: Operational Excellence, Health and Safety, Oil and Gas, Environmental performance, Accident, Risk

\section{Introduction}

Stiffer regulations, the rise in the cost of production, health, safety and environmental issues are some of the daring challenges faced by the oil and gas sector in recent time. Other complexities include pricing framework, advancement in technology, ageing of assets, continued depletion of oil reserves (Mustapha, Umeh \& Adepoju, 2015). Also, the increasing stakeholders demand oil firms perform at all cost is the current situation in the oil and gas industry. These pressures compelled the firms in the sector to develop and adopted a strategy that helped them reduce and control some of the challenges. Thus the top strategic priority for oil and gas firms remains operational excellence for cost reduction, and health and safety programs (PwC, 2017). With operational excellence in place, primary containment loss drops by $40 \%$ - 50\%, export deferrals declines by $98.5 \%$ and emergency and reactive activities reduces by $80 \%-90 \%$ (McCreery, Philips \& Cigala, 2013). 
Operational Excellence (OE) strategy was adopted and implemented by the majority of the Integrated Oil Companies (IOCs) like Chevron, Mobil, Eni, Total, Statoil, Shell to mention a few (Ernst \& Young, 2015). And the results were encouraging, as some of the issues were put under control; however, the situation is different for National Oil Companies (NOCs) because the majority of them did not adopt operational excellence due to their peculiarities of ownership. Thus the landmark of most change in organisations is related to resources available to the organisation. In this case, therefore, the underpinning theory that supports the implementation of operational excellence is the Resource Based View (RBV) theory (Fok-Yew \& Ahmad, 2014; Shehadeh et al., 2016; Soliman, 2017). The theory spells out that firms should use their internal strength or resources (people, assets, money, technologies) to manage internal and external environment challenging situations.

The Nigerian oil and gas industry renewed efforts to improve efficiency to reduce production costs across the industry by establishing remarkable fabrication and integration infrastructure in-country, on which future deepwater projects could latch to reduce cost (DPR, 2016). It is proven that engineering is done $90 \%$ in-country and $50 \%$ fabrications of tonnage are also done in Nigeria $(\mathrm{PwC}, 2014)$. Again Nigerian Liquefied Natural Gas (LNG) as a coowned subsidiary of the Nigerian National Petroleum Corporation (NNPC) is evidence of operational excellence implementation. The firm attained transition to stable production operation with a vigorous framework of people, processes, systems and organisation due to strategy implementation (LNG, 2017). The strategy improves asset reliability and health, safety, security and environmental performance of the firm. Of course, operational excellence goes further than cost-cutting; it guarantees safe, reliable and efficient operation as business essentials in the oil sector (PwC, 2017). In Nigerian oil and gas sector as a whole, the situation is no different, as efforts put into controlling the operational risks and incidents has not changed the trend in the entire industry, as it is still prevalent in recent years.

Several studies were conducted in the sector to ascertain the effect of the strategy such as lean, total quality management and efficiency in the performance of the industry but their findings were not encouraging. Studies conducted across so many industries by Oke and Kareem (2013); Ahmad (2014); Uzochukwu and Ossai (2016); Ifeanyichukwu (2010); PwC (2014); Amue and Ozuru (2014); Mustapha et al. (2014); and Maleka, Hove and Karodia (2014) on operational excellence, efficiency, lean management, total quality management in the Nigerian oil sector. Regardless of the studies' efforts, the situation provides no clear dimension as to what are the real causes of the problems and their implication if not managed well. It is against this backdrop that this article reviewed the literature and antecedents of research on operational excellence and related field to understand the actual problems and their root causes. Again it is aimed at unravelling the performance of the NNPC with concerns to refineries capacities, health and safety, the environment and revenue generation to the government over the years.

\subsection{Literature Review}

Operational excellence (OE) has been adopted and used by many organisations across industries. It is a strategy that facilitates an increase in productivity, quality, flexibility, cost reduction, lead time optimisation in organisations' operations (Fok-Yew \& Ahmad, 2014; Shehadeh et al., 2016; Kandasamy, 2016). It is seen as a way of continuous improvement in operational processes in organisations (Soliman, 2017). OE is a strategy that enables operational efficiency, as it measures the ability of an organisation to achieve output with little input (Kumar and Gulati, 2009). In a highly regulated environment like the oil and gas sector, compliance is always at the forefront because of the nature of the risk involved. Therefore, to reach excellence in operations, a firm must find innovative ways to incorporate compliance into its production and operation infrastructure. According to (Muazu \& Tasmin 2017; Heath, 2017; Edgame, 2014; Chevron, 2010) OE is the continuous pursuance of industrial best practices in health and safety, operational efficiency, assets and process reliability and environmental performance. These would bring about employees confidence and motivation to drive organisational performance and when efficiency is achieved, assets become reliable for smooth operations and profitability could be projected.

Health safety and the environment is one of the cardinal objectives of firms in the oil and gas industry, whether IOC or NOC. The performance in HSE in the industry increases the reputation of firms to both their employees and other stakeholders. Ratna and Kaur (2017) see health and safety as the maintenance of mental, physical and social wellbeing of the workforce. Health and safety represent employees' exposure to hazardous and risky undertakings (Fuller \& Vassie, 2001). According to Kolios and Luengo (2016), HSE is compliance issues that must be given priority in the oil and gas operations. An effective safety system facilitates reliable operations of the firm's assets, operational efficiency and ultimately superior financial performance (British Petroleum BP, 2016). Wilson (2012) posited that HSE performance is one of the starting points for achieving operational excellence in the oil and gas sector. The environment is comprised of the host communities where oil production activities are taking place, the animals, vegetation and the climate. According to Graham and McAdam, (2016) the efforts made by oil firms to reduce the effects of their operations on the environment (spillage, fires) is regarded as the environmental performance. 


\subsection{Methodology}

The article is a review paper, which reviewed literature on the field of operational excellence in general and its dimensions in the oil and gas. Reports, term papers, professional insights, theses and journal articles were reviewed and reported. Statistical data and figures were drawn and discussed in tables. Percentage values were integrated and summed up from the reports to show in a simplified format the captured figures and statistics of revenues, losses, incidences and outputs from the activities of the NNPC.

\subsection{Results and Discussion}

The findings show that the country's oil sector had a high level of inefficiency (technical and cost) of 0.51 between the periods of 2006-2009 (Oke \& Kareem, 2013). Again literature revealed that NNPC adopted Total Quality Management (TQM) culture and customer focus as opined by Okoye (2010). Nonetheless, this effort has failed to transform the corporation quality and low cost orientated operations into the firm performance. Also, since the firm's operations key decisions are determined from the centre, according to (Adam, 2014) these operational decisions are often slowed, and too much bureaucracy affects operational efficiency and effectiveness of NNPC. It was also reported that NNPC staff at both lower and middle cadre have a great deal of experience concerning oil and gas sector, but on a general note, the corporation lacks sufficient human capacity (Thurber et al., 2010).

The laws governing NNPC's operations are outdated (Adam, 2014) and all effort to update the framework were seemed to be rejected by some stakeholders. Unfortunately, Nigeria lacks strong institutions, policies, monitoring and implementation tenacity as argued by Allen (2010) and that the situation gave room for international oil companies to swindle their ways against the wishes of governments and communities stakeholders. The oil companies polluted the environment and got away with it without being held accountable for their actions. The petroleum industry bill (PIB) was submitted to the national assembly for over eight years now but was not passed by the two houses. The bill was proposed by the then government of Goodluck Jonathan in 2009 to reform the Nigerian oil sector to cater for local content and indigent communities' development, livelihood and resource control. Some of the reasons for the delay in the passage of the bill may not be unconnected with the conflict against stakeholders' interests in the industry and corruption. Regrettably, the bill was restructured to favour some key players of the industry, as insinuated that is why the problems in the oil-rich Niger-delta is never near to finish. The continued situation gave rise to the resurgence of militant's activities in the region, which by implication affects oil production and by extension affects government revenues and foreign investments in the sector.

According to Ostebo et al. (2018) HSE, cost control, quality and sustainability are some of the major objectives of the oil and gas industry, so it requires reliable, safe and cost-effective strategies to achieve that. So for HSE performance to be improved in the Nigerian oil sector, all-inclusive enterprise-wide risk management strategy must be implemented (Dabup, 2012). Conversely, the situation in the oil and gas sector as opined by Zoufa and Ochieng (2014) is bothersome because risk management literacy was very poor. Therefore managing health and safety remained a challenge for NNPC and the entire industry.

Issues related to the accident (fatal and non-fatal, work-related and non-work related) as reported by DPR (2016) indicated that 50-57 incidents were recorded in 2010, 2011, 2013 and 2016 respectively as shown in Table 1 below. A number of fatalities were quite high, as 86 fatalities were experienced in 2015 , although it drastically dropped to 38 in 2016 it is still worrisome because many organisations desire to register zero fatality in all operations.

Table 1 - Nigerian Oil and Gas Industry Accident Report

\begin{tabular}{lcccccccc}
\hline $\begin{array}{l}\text { Incident } \\
\text { Year }\end{array}$ & Incidents & $\begin{array}{l}\text { Work } \\
\text { Related }\end{array}$ & $\begin{array}{l}\text { Non- } \\
\text { Work } \\
\text { Related }\end{array}$ & $\begin{array}{l}\text { Non- } \\
\text { Fatal } \\
\text { Accidents }\end{array}$ & $\begin{array}{l}\text { Work- } \\
\text { Related } \\
\text { Fatal } \\
\text { Accidents }\end{array}$ & $\begin{array}{l}\text { Non-Work } \\
\text { Related } \\
\text { Fatal } \\
\text { Accidents }\end{array}$ & $\begin{array}{l}\text { Fatal } \\
\text { Accidents }\end{array}$ & Fatality \\
\hline 2010 & 50 & 24 & 26 & 29 & 6 & 15 & 21 & 25 \\
2011 & 53 & 29 & 24 & 34 & 6 & 13 & 19 & 19 \\
2012 & 49 & 27 & 22 & 22 & 12 & 15 & 27 & 35 \\
2013 & 57 & 29 & 28 & 39 & 7 & 11 & 18 & 30 \\
2014 & 40 & 15 & 25 & 25 & 1 & 14 & 15 & 22 \\
2015 & 49 & 24 & 25 & 17 & 14 & 18 & 32 & 86 \\
2016 & 50 & 24 & 16 & 29 & 8 & 13 & 21 & 38 \\
\hline
\end{tabular}

Source: DPR (2016), NNPC (2017)

Environmental wastes and spillage on Table 2 below also revealed that there are 4850 oil spill incidents and $118,118.65 \mathrm{~m}$ barrels of oil were released to the environment from 2010-2016. Also, 741,495 barrels productions were 
deferred as a result of the unplanned shut down necessitated by vandalisation of facilities and operational failures and other challenges (DPR, 2016). There was a 9.6\% decline over the average production rate for 2015.

Table 2 - Oil and Gas Spill Incidence in Nigeria

\begin{tabular}{ccc}
\hline Year & Number of Spills & $\begin{array}{c}\text { The quantity of } \\
\text { Spilled (Barrels) }\end{array}$ \\
\hline 2010 & 537 & $17,658.10$ \\
2011 & 673 & $66,906.84$ \\
2012 & 844 & $17,526.37$ \\
2013 & 522 & $4,066.20$ \\
2014 & 1087 & $10,302.16$ \\
2015 & 753 & $32,756.87$ \\
2016 & 434 & $1,658.98$ \\
Total & 4850 & $118,118.65$ \\
\hline Source: DPR (2016) & &
\end{tabular}

The refineries in Nigeria are owned and operated by the government corporation known as NNPC. The NNPC refineries were performing below capacity, to as low as 5.43\% - 15.52\% in 2014-2016 (DPR, 2016). The planned capacity for the three refineries Kaduna Refinery and Petrochemical Company (KRPC), Warri Refinery and Petrochemical Company (WRPC) and Port Harcourt Refining Company (PHRC) were 110000, 125000, and 150000 barrels respectively. The statistics have shown that the optimum utilisation was at $26.61 \%$ capacity in 2011 and afterwards, it kept on declining to as low as $5.43 \%$ in 2015 . The situation is bothersome as it cost the country and NNPC colossal cost burden on importing petroleum motor spirit (PMS) and other petroleum products to meet the demands of Nigerians. NNPC imported $8.6 \mathrm{~m}$ metric tons of petrol in 2008, $15.27 \mathrm{~m}$ metric tons in 2011 and $13.55 \mathrm{~m}$ $\mathrm{m} /$ tons in 2016 (DPR, 2016). By implication it means that if those refineries were fully operational, even say at $50 \%$ capacity, a lot of money will have been saved for other functions of government. It is unfortunate that the government have to pay petroleum subsidies through its nose because in 2018 some marketers threaten a total shutdown of PMS supply if their outstanding subsidy payment in the tune N800 billion or thereabout.

Table 3 - NNPC Refineries Capacity Utilization

\begin{tabular}{lllllc}
\hline & KRPC & WRPC & PHRC & Total & $\begin{array}{c}\text { Capacity } \\
\text { Utilization } \\
\%\end{array}$ \\
\hline $\begin{array}{l}\text { Designed } \\
\text { Capacity }\end{array}$ & 110,000 & 125,000 & 150,000 & $385,000.00$ & \\
\hline 2010 & $21,986.72$ & $53,345.20$ & $19,345.38$ & $94,677.30$ & $24.59 \%$ \\
2011 & $20,896.79$ & $49,731.41$ & $31,853.02$ & $102,481.22$ & $26.61 \%$ \\
2012 & $31,981.86$ & $34,868.71$ & $24,530.97$ & $91,381.54$ & $23.73 \%$ \\
2013 & $32,452.43$ & $20,925.04$ & $44,937.47$ & $93,314.94$ & $24.23 \%$ \\
2014 & $12,160.39$ & $24,049.59$ & $23,557.15$ & $59,767.13$ & $15.52 \%$ \\
2015 & $3,297.36$ & $8,337.64$ & $9,274.21$ & $20,918.21$ & $5.43 \%$ \\
2016 & $10,310.69$ & $14,746.13$ & $32,669.98$ & $57,726.80$ & $14.99 \%$ \\
2017 & $29.9 \%$ may & $9.9 \%$ April & $34.3 \%$ may & & \\
\hline
\end{tabular}

Source: DPR (2016) and NNPC (2017)

The findings further show that oil and gas proceeds to the government were N1.016trln, N587.6bn and N462.7bn in 2014,2015 and 2016 respectively. Its contribution to GDP is third to services and agriculture as it contributed $10.79 \%$ and $77 \%$ to government revenues in 2014 (NEITI, 2016). 
Table 4 - Revenue Performance of the Nigerian oil and Gas Sector

\begin{tabular}{lllllll}
\hline Years & \multicolumn{1}{c}{$\begin{array}{c}\text { Oil } \\
\text { Royalties }\end{array}$} & $\begin{array}{c}\text { Gas } \\
\text { Royalties }\end{array}$ & $\begin{array}{c}\text { Gas } \\
\text { Flared } \\
\text { Penalties }\end{array}$ & $\begin{array}{c}\text { Concessi } \\
\text { on Rentals }\end{array}$ & $\begin{array}{c}\text { Miscellaneo } \\
\text { us Oil Revenues }\end{array}$ & $\begin{array}{c}\text { Total } \\
\text { Revenue }\end{array}$ \\
\hline 2010 & $694.352 \mathrm{bn}$ & 0.00 & $2.388 \mathrm{bn}$ & $728.308 \mathrm{~m}$ & $951.389 \mathrm{~m}$ & $698.420 \mathrm{bn}$ \\
2011 & $1.066 \mathrm{trn}$ & $14.613 \mathrm{bn}$ & $3.482 \mathrm{bn}$ & $388.502 \mathrm{~m}$ & $2.077 \mathrm{bn}$ & $1.087 \mathrm{trn}$ \\
2012 & $1.052 \mathrm{trn}$ & $22.242 \mathrm{bn}$ & $3.849 \mathrm{bn}$ & $444.535 \mathrm{~m}$ & $1.370 \mathrm{bn}$ & $1.079 \mathrm{trn}$ \\
2013 & $960.540 \mathrm{bn}$ & $23.235 \mathrm{bn}$ & $3.120 \mathrm{bn}$ & $178.630 \mathrm{~m}$ & $3.981 \mathrm{bn}$ & $991.056 \mathrm{bn}$ \\
2014 & $986.343 \mathrm{bn}$ & $21.110 \mathrm{bn}$ & $2.930 \mathrm{bn}$ & $413.496 \mathrm{~m}$ & $5.983 \mathrm{bn}$ & $1.016 \mathrm{trn}$ \\
2015 & $545.061 \mathrm{bn}$ & $22.292 \mathrm{bn}$ & $2.590 \mathrm{bn}$ & $201.275 \mathrm{~m}$ & $17.489 \mathrm{bn}$ & $587.634 \mathrm{bn}$ \\
2016 & $437.356 \mathrm{bn}$ & $16.298 \mathrm{bn}$ & $2.333 \mathrm{bn}$ & $342.495 \mathrm{~m}$ & $6.408 \mathrm{bn}$ & $462.740 \mathrm{bn}$ \\
\hline Total & $\mathbf{5 . 7 4 2 t r n}$ & $\mathbf{1 1 9 . 7 9 2 b n}$ & $\mathbf{2 0 . 6 9 6 b n}$ & $\mathbf{2 . 6 9 7 b n}$ & $\mathbf{3 8 . 2 6 1 b n}$ & $\mathbf{5 . 9 2 3 t r n}$ \\
\hline
\end{tabular}

Source: DPR (2016), NNPC (2015

In Table 4 there is a plunging trend in the government revenue in 2010 - 2016. Considering the overall revenues from 2014-2016, it dropped from N1.016 trillion to N587.634 billion in 2015 and N462.740 billion in 2016. Some of the causes of the fall in revenue are the activities of the Niger Delta Militants, fall in price, the drop in export and USA demand for Nigerian crude in the said period. Technical issues of facility shutdown and production deferment in some strategic oil wells also affected oil production (Adam, 2014).

\subsection{Conclusion}

This article was able to prove that indeed the oil sector is still the major contributor of revenue to the economy and third in GDP. Oil spillage and gas flaring is no way near stopping; outdated regulations are governing operations, poor staff capacity and rising political interference. There are again, increasing unplanned plant shutdown and production deferments due to some recurrent issues within and outside the NNPC. From the above arguments and figures, one could deduce that there are still issues that were not managed sufficiently; that's why the recurrences of HSE incidents and facilities breakdown leading to the drop in performance. To this end, this paper suggests that Nigerian oil sector; particularly the NNPC should imbibe risk management culture and training, deploy recent and dynamic technologies, employ enterprise-wide risk management strategy and upgrade the entire regulatory framework governing oil and gas production value chain. This is with the view to improving operational excellence strategy implementation, and as such HSE performance, efficiency, productivity and even revenue generation to the government of Nigeria could improve.

\subsection{Reference}

Adam, I., S. (2014). An Empirical Investigation of the Efficiency, Effectiveness and Economy of the Nigerian National Petroleum Corporation's (NNPC) Management of Nigeria' Upstream Petroleum Sector. Unpublished Thesis of the Robert Gordon University Aberdeen.

Allen, F., (2010). Implementation of Oil-related Environmental Policy in Nigeria; government inertia \& conflict in the Niger Delta. PhD (Political Science) Thesis. Durban: University of KwaZulu Natal.

Amue, G. J. \& Ozuru, H. (2014). Supply Chain Integration in Organizations: An Empirical Investigation of the Nigeria Oil and Gas Industry. International Journal of Marketing Studies, 6(6), 129-140.

British Petroleum (2016). Annual Report and Form 20-F. accessed 22/07/2018

https://www.bp.com/content/dam/bp/en/corporate/pdf/investors/bp-annual-report-and- form-20f-2016.pdf

Chevron Corporation, (2010). Operational Excellence Management System; an Overview of the OEMS. Chevron U.S.A. Inc.

Dabup, N., L. (2012). Health, Safety and Environmental Implications in Nigeria's Oil and Gas Industry. Unpublished PhD Thesis, Faculty of Engineering, Nelson Mandela Metropolitan University, Port Elizabeth, South Africa.

DPR (2016). Oil and Gas industry Annual Report. Lagos: Department of Petroleum Resources. Nigeria. 
Edgeman, R. (2014). Modelling \& Analytics of Sustainable, Resilient and Robust Enterprises. Business System Review Special Issue. Volume 3 - Issue 2, pp75-99. Selected papers of the 2nd B.S.Lab International Symposium.

Ernst \& Young (2015). Driving Operational Performance in the Oil and Gas. EY global limited business Report.

Fok-Yew, O., and Ahmad, H., 2014. The Effect of Change Management on Operational Excellence in Electrical and Electronics Industry: Evidence from Malaysia. British Journal of Economics, Management \& Trade, 4(8), $1285-1305$. doi: 10.9734/BJEMT/2014/9201.

Fuller, C., W. \& Vassie, L., H. (2001). Benchmarking the Safety Climates of Employees and Contractors Working within a Partnership Arrangement - A case study in the offshore oil industry. International Journal 8(5), pp 413-430.

Graham, S., \& McAdam, R. (2016). The Effects of Pollution Prevention on Performance. International Journal of Operations \& Production Management, 36(10), 1333-1358. DOI: 10.1108/IJOPM-05-2015-0289.

Heath, B., Peterson, R., Marcontell, D., \& Scott, S. (2017). What Oil and Gas can Learn From Aviation A New Cyclical Reality Makes Energy Companies Rethink Operation. Oliver Wyman' Energy Journal, 03, 24-27

Ifeanyichukwu, O. C. (2010). Organizational Performance Improvement in Oil Producing Facility in Nigeria through Operational Excellence. Unpublished Thesis, North-West University, South Africa.

Kandasamy, S. (2016). Enhancing Customer Value: The Principles of Value Addition. The International Journal of Business \& Management, 4 (1), 198-203.

Kolios, A., J. \& Luengo, M., M. (2016). Operational Management of Offshore Energy Assets. Journal of Physics: Conference Series 687, 1-7. 012001, doi:10.1088/1742-6596/687/1/012001

Kumar, S. \& Gulati, R. (2009). Measuring Efficiency, Effectiveness and Performance of Indian Public Sector Banks. International Journal of Productivity and Performance Management, 59(1), 51-74.

Maleka, N.A; Hove, G; \& Karodia, A.N. (2014). Assessing the Implementation of a Lean Six Sigma Improvement Programme: A Case Study of the Rail Engineering Organization in Gauteng Province. Arabian Journal of Business and Management Review 2 (6), 25-70.

McCreery, J., Phillips, E. \& Cigala, F. (February 2013). Operational excellence: The imperative for oil and gas companies. Bain Brief, February. Bain \& Company Publications.

Muazu, H., M. \& Tasmin, R., (2017). Operational Excellence in Manufacturing, Service and the Oil and Gas: the Sectorial Definitional Constructs and Risk Management Implication. Traektoriâ Nauki = Path of Science, 3 (9), 3001 3008. doi: 10.22178/pos.26-4.

Mustapha, A., Umeh, N. \& Adepoju, A. (2015). Deploying Continuous Improvement Methodologies to Improve Efficiency: A Way of Responding to Emerging Industry Challenges. Nigeria Annual Int'l Conference and Exhibition, $4^{\text {th }}-6^{\text {th }}$ August, Lagos Nigeria.

NEITI (2016). Oil and Gas Industry Audit Report, 2014. https://eiti.org/sites/default/files/documents/neiti-oil-gasreport-2014-full-report-301216.pdf

Nigeria LNG (2017). Facts and Figures on Nigeria Liquefied Natural Gas. An Annual Compendium of Information about NLNG.

Oke, D. M. \& Kareem, S. D. (2013). An Inter-temporal Analysis of Operational Efficiency of Oil Firms: Further Evidence from Nigeria. International Journal of Energy Economics and Policy, 3(2), 178-184.

Okoye, C. I., D. (2010). Transformation Programs in NNPC and Corporate Performance, Unpublished NNPC Chief Officers' Management Development Programme Course 059 Project Report.

Ostebo, R., Selvik, J. T., Naegeli, G. \& Ciliberti, T. (2018). ISO Standards to Enable Reliable, Safe and Cost-Effective Technology Development, Project Execution and Operational Excellence. Offshore Conference in Houston Texas, USA $30^{\text {th }}$ April - $3^{\text {rd }}$ May. OTC-28705-MS. 
PricewaterhouseCoopers PwC (2017). Learning to Leapfrog: Africa Oil and Gas Review. Report on Current Developments in the Oil \& Gas Industry in Africa, November.

Uzochukwu, O. C. \& Ossai, I. F. (2016). Lean Production: A Frontier for Improving Performance of Oil and Gas Companies in Nigeria. Pyrex Journal of Business and Finance Management Research, 2(5), 35-41.

Ratna, R. \& Kaur, T. (2016). The Impact of Information Technology on Job Related Factors like Health and Safety, Job Satisfaction, Performance, Productivity and Work-Life Balance. Journal of Business Financial Affairs. 5(1), 1-9.

Soliman, M. H. A. (2017). Why Continuous Improvement Programs fail in the Egyptian Manufacturing Organizations? A Research Study of Evidence. American Journal of Industrial and Business Management, 7, 202-222.

Thurber, M. C., Emelife, I., F. \& Heller, P., R. (2010). NNPC and Nigeria's Oil Patronage Ecosystem. Program on Energy and Sustainable Development, Stanford University, Stanford.

Wilson, A. (2012). Operational Excellence: Harmonising Business Goals and Departmental Priorities to Create Sustainable Business. Proceedings of SPE/APPEA International Conference on Health, Safety and Environment in Oil and Gas Exploration and Production held in Perth, Australia on 11-13 September 2012

Zoufa, T. \& Ochieng, E., G. (2014). Issues in Risk Management: The Perspectives of Managers in Nigeria's Oil and Gas Industry. International Journal of Engineering Research \& Technology, 3(4), 369-374. 